\title{
CHILDREN'S INDOOR EXPOSURES TO (ULTRA)FINE PARTICLES IN AN URBAN AREA: COMPARISON BETWEEN SCHOOL AND HOME ENVIRONMENTS
}

\author{
Klara Slezakova, Cátia Texeira, Simone Morais, Maria do Carmo Pereira
}

\begin{abstract}
Due to their detrimental effects on human health, scientific interest in ultrafine particles (UFP), has been increasing but available information is far from comprehensive. Children, who represent one of the most susceptible subpopulation, spend the majority of time in schools and homes. Thus, the aim of this study is to (1) assess indoor levels of particle number concentrations (PNC) in ultrafine and fine $(20-1000 \mathrm{~nm})$ range at school and home environments and (2) compare indoor respective dose rates for 3- to 5-yr-old children. Indoor particle number concentrations in range of $20-1000 \mathrm{~nm}$ were consecutively measured dur-ing $56 \mathrm{~d}$ at two preschools (S1 and S2) and three homes (H1-H3) situated in Porto, Portugal. At both preschools different indoor microenvironments, such as classrooms and canteens, were evaluated. The results showed that total mean indoor PNC as determined for all indoor microenvironments were significantly higher at S1 than S2. At homes, indoor levels of PNC with means ranging between $1.09 \times 10^{4}$ and $1.24 \times 10^{4}$ particles $/ \mathrm{cm}^{3}$ were $10-70 \%$ lower than total indoor means of preschools $\left(1.32 \times 10^{4}\right.$ to $1.84 \times 10^{4}$ particles $\left./ \mathrm{cm}^{3}\right)$. Nevertheless, estimated dose rates of particles were 1.3- to 2.1-fold higher at homes than preschools, mainly due to longer period of time spent at home. Daily activity patterns of 3- to 5-yr-old children significantly influenced overall dose rates of particles. Therefore, future studies focusing on health effects of airborne pollutants always need to account for children's exposures in different microenvironments such as homes, schools, and transportation modes in order to obtain an accurate representation of children overall exposure.
\end{abstract}

During the last two decades, there has been considerable interest in the health effects of exposure to airborne particulate matter (PM) (Krewski et al., 2003; Krewski and Rainham, 2007; Samet and Krewski, 2007; Brunekreef et al., 2009). As knowledge regarding adverse health effects being correlated with size dependency of particles has grown (Kelly and Fussel, 2012), ongoing research has focused attention on ultrafine particles (UFP), which represent a fraction of particulate matter (PM) with particles of aerodynamic diameter smaller than $0.1 \mu \mathrm{m}$ (Morawska et al., 2013; Carosino et al., 2015).
Unlike coarse particles, UFP contribute little to PM mass, but these dominate number concentrations. Due to UFP small size, high number concentrations, high surface area, and ability to penetrate into the interstitial spaces of the lungs (Bakand et al., 2012; Pereira Gomes et al., 2012), there are various adverse health effects. Clinical and epidemiological studies linked exposure to ambient UFP with adverse respiratory outcomes, including impaired lung function and pulmonary defense mechanisms, inflammatory responses and worsening of respiratory diseases, and possibly cardiovascular 
dysfunction (Ibald-Mulli et al., 2002; Bakand et al., 2012; Heal et al., 2012; Tsai and Yang, 2014; Chang et al., 2015), although findings are not consistent (Rückerl et al., 2011). While more epidemiological studies on the UFP fraction are needed, exposure assessment issues such as spatial variability, indoor sources, infiltration of UPF from various outdoor emission sources, and seasonal variability in concentrations and composition are currently being addressed (Wang et al., 2013; Azarmi et al., 2014; Bekö et al., 2013; Viana et al., 2014, 2015; Rivas et al., 2015).

In view of the evidence of negative health impacts of UFP, studies focused on investigation of main sources and processes affecting levels and size distributions of these particles in ambient air of urban areas (Morawska et al., 2008; Kumar et al., 2010; Solomon, 2012). UFP may be formed by condensation of semivolatile organic aerosols, photochemically induced nucleation, and/or nucleation through gas-to-particle conversion (Morawska et al., 2008, 2013). Concerning indoor air, UFP originate from combustion processes that include cooking, namely, boiling, stewing, frying, baking, and grilling, smoking, and use of candles (Bekö et al., 2013; Morawska et al., 2013), and as result of occupant-related activities such as use of consumer products and use of painting and cleaning products (Long et al., 2000; Bhangar et al., 2011).

Young children represent one of the most susceptible subpopulations with regard to potentially harmful effects induced by airborne PM exposure (Schüepp and Sly, 2012; AnnesiMaesano et al., 2013). As their physiological and immunological systems are still developing, young children receive a higher dose of airborne particles relative to lung size compared to adults (Foos et al., 2008; Burtscher and Schüepp, 2012; Morawska et al., 2013; Laiman et al., 2014; Mazaheri et al., 2014). Children spend a significant percent of time at schools and at homes. Specifically, in Portugal, young children spend at school approximately $30 \%$ of their time (8-9 h/d). Therefore, knowledge and understanding of indoor air pollution in these specific environments are important in order to improve child health. As a pollutant of both indoors and in ambient air, UFP possess the potential to harm children's health (Burtscher and Schüepp, 2012; Schüepp and Sly, 2012; Moreno et al., 2014; Reche et al., 2014; Rivas et al. 2014; Viana et al., 2014), yet information concerning children's exposure to UFP is limited.

The aim of this study was to assess indoor exposure to particles in the (ultra)fine range (20-1000 nm) in 3- to 5-yr-old children living in urban areas. The specific objectives were to (i) measure levels of indoor particle number concentrations (PNC) in two preschools and three homes situated in urban low to moderate traffic zones of Oporto Metropolitan Area (Portugal), and (ii) compare dose rates of indoor (ultra)fine particles at schools and home environments.

\section{MATERIALS AND METHODS}

\section{Characterization of Sampling Sites}

Particle number concentrations in ultrafine (20-100 nm) and fine (>100-1000 nm) ranges were consecutively measured at two preschools and three homes, all of them situated in urban low to moderate traffic zones of Oporto Metropolitan Area in Paranhos district (north of Portugal). The sample collection was conducted for $56 \mathrm{~d}$. Both the preschools (S1 and S2) and homes $(\mathrm{H} 1-\mathrm{H} 3)$ were situated in an urban zone; previously studies that evaluated ambient air pollution demonstrated that emissions from vehicular traffic are the main pollution source in these areas (Slezakova et al., 2011, 2013).

In each preschool, PNC were simultaneously measured in different indoor microenvironments, including classrooms, canteens, and, if present, gymnasium or playroom; all microenvironments were assessed using identical sampling methodology and for the same amount of time. At homes, sampling of (ultra)fine particles was conducted in living rooms that were used also as dining rooms; all meals/snacks were served there. 
TABLE 1. Characterization of the Studied Environments (Preschools and Homes) and Obtained Concentrations of (Ultra)Fine Particles

\begin{tabular}{|c|c|c|c|c|c|c|c|}
\hline \multirow[b]{2}{*}{ Site } & \multirow[b]{2}{*}{ Description } & \multirow[b]{2}{*}{ Location } & \multirow[b]{2}{*}{$\begin{array}{l}\text { Traffic density } \\
\text { data }^{\mathrm{a}}\end{array}$} & \multirow[b]{2}{*}{$\begin{array}{l}\text { Studied indoor } \\
\text { microenvironments }\end{array}$} & \multirow[b]{2}{*}{$\begin{array}{l}\text { Sampled } \\
\text { period }\end{array}$} & \multicolumn{2}{|c|}{$\begin{array}{l}\text { Particle number concentration } \\
\text { (particles } / \mathrm{cm}^{3} \text { ) }\end{array}$} \\
\hline & & & & & & Mean & $\begin{array}{l}\text { Standard } \\
\text { deviation }\end{array}$ \\
\hline S1 & $\begin{array}{l}\text { Two-floors building } \\
173 \text { students } 3-5 \mathrm{yr} \\
\text { old }\end{array}$ & $\begin{array}{l}\text { Situated on } \\
\text { moderately } \\
\text { trafficked street }\end{array}$ & $\begin{array}{l}\text { Mean: } 16 \\
\quad \text { vehicles/ } \\
\text { min }\end{array}$ & $\begin{array}{l}\text { Classrooms (3) } \\
\text { Canteen (1) } \\
\text { Playroom (1) }\end{array}$ & $13 d$ & $\begin{array}{l}\text { Classrooms } 9.31 \times 10^{3} \\
\text { Canteen } 5.17 \times 10^{4} \\
\text { Playroom } 1.70 \times 10^{4} \\
\text { Total } 1.82 \times 10^{4}\end{array}$ & $\begin{array}{l}8.23 \times 10^{3} \\
3.41 \times 10^{4} \\
1.25 \times 10^{4} \\
2.16 \times 10^{4}\end{array}$ \\
\hline S2 & $\begin{array}{l}\text { Three-floors building } \\
30 \text { students } 3-5 \text { yr old }\end{array}$ & $\begin{array}{l}\text { Situated on } \\
\text { intersection of } \\
\text { moderate and low } \\
\text { trafficked street }\end{array}$ & $\begin{array}{l}\text { Mean: } 13 \\
\text { vehicles/ } \\
\text { min }\end{array}$ & $\begin{array}{l}\text { Classrooms (3) } \\
\text { Canteen (1) } \\
\text { Gymnasium (1) }\end{array}$ & $13 d$ & $\begin{array}{l}\text { Classrooms } 1.13 \times 10^{4} \\
\text { Canteen } 3.28 \times 10^{4} \\
\text { Gymnasium } 9.72 \times 10^{3} \\
\text { Total } 1.32 \times 10^{4}\end{array}$ & $\begin{array}{l}5.24 \times 10^{4} \\
3.21 \times 10^{4} \\
2.36 \times 10^{3} \\
1.25 \times 10^{4}\end{array}$ \\
\hline $\mathrm{H} 1$ & $\begin{array}{l}\text { Multiunit apartment } \\
\text { building } \\
\text { Situated on fourth } \\
\text { floor, } 4 \text { occupants } \\
\text { ( } 2 \text { children, } 3 \text { and } \\
5 \text { yr old) }\end{array}$ & $\begin{array}{l}\text { Situated on } \\
\text { intersection of } \\
\text { two low trafficked } \\
\text { street }\end{array}$ & $\begin{array}{l}\text { Mean: } 3 \\
\text { vehicles/ } \\
\text { min }\end{array}$ & Living room & $10 d$ & $1.24 \times 10^{4}$ & $1.28 \times 10^{4}$ \\
\hline $\mathrm{H} 2$ & $\begin{array}{l}\text { Multiunit apartment } \\
\text { building } \\
\text { Situated on fourth } \\
\text { floor, } 4 \text { occupants } \\
\text { ( } 1 \text { child } 5 \text { yr old), }\end{array}$ & $\begin{array}{l}\text { Situated nearby } \\
\text { highly trafficked } \\
\text { road }\end{array}$ & Not available & Living room & $9 d$ & $1.11 \times 10^{4}$ & $1.15 \times 10^{4}$ \\
\hline $\mathrm{H} 3$ & $\begin{array}{l}\text { Two-floor house } \\
4 \text { occupants ( } 1 \text { child, } \\
5 \text { yr old) }\end{array}$ & $\begin{array}{l}\text { Situated in suburban } \\
\text { zone with } \\
\text { moderate traffic }\end{array}$ & $\begin{array}{l}\text { Mean: } 4 \\
\text { vehicles/ } \\
\text { min }\end{array}$ & Living room & $11 \mathrm{~d}$ & $1.09 \times 10^{4}$ & $1.11 \times 10^{4}$ \\
\hline
\end{tabular}

${ }^{a}$ Data were obtained by manual counts during $10 \mathrm{~min}$ of each hour (between 5 a.m. to 12 p.m.) on two consecutive days (avoiding Mondays and Fridays). The distance between the counting point and main entrance/building outside wall was 5 and $8 \mathrm{~m}$ at S1 and S2, respectively, and 3-4 $\mathrm{m}$ at $\mathrm{H} 1$ and $\mathrm{H} 3$.

All indoor locations were naturally ventilated through open windows. The characteristics of the studied preschools and homes, traffic density data, and duration of sampling at each place are summarized in Table 1.

\section{Sample Collection}

Particle number concentrations in size range $0.02-1 \mu \mathrm{m}$ were measured by condensation particle counters, TSI P-Trak ${ }^{\text {TM }}$ (UPC 8525; TSI, Inc., Shoreview, MN). The instrument operates on the principle of condensing $100 \%$ grade isopropyl alcohol (Sigma-Aldrich, Steinheim, Germany) onto UFP in order to increase their dimensions to a detectable size. At preschools, PNC were measured daily between 8:30 a.m. and 5:30 p.m., which corresponded to the period that children were at preschools, whereas at homes PNC of (ultra)fine particles were measured continuously over $24 \mathrm{~h}$. Intake flow of $0.7 \mathrm{~L} / \mathrm{min}$ was used and logging interval was $60 \mathrm{~s}$, according with previous studies (Diapouli et al., 2007; Norbäck et al., 2011; Zhang and Zhu, 2012). Instruments were mounted onto supports so that air was sampled from a height of 0.8 to $1.1 \mathrm{~m}$ (in order to simulate children's breathing zone). In each indoor environment, particles counters were placed as far as possible from windows or doors, and from other probable sources of particles such as heating equipment, blackboards, and printers, in order to minimize direct influence of any source. All requirements to maintain child safety were fulfilled.

At both preschools a researcher was present during sample collection in order to keep a record of room occupancy, ventilation systems (door and window positions), and potential source activities; information concerning child activities and schedules at preschools was also registered by an investigator. At homes, all information including child activities was recorded by the parents/child responsible. In addition, 
teachers, staff, and parents were asked daily about the occurrence of additional sources and activities. Further, detailed questionnaires were used daily for better description of the studied indoor environments for both preschools and homes. The first questionnaire was dedicated to registering potential sources of particles, where the occupants marked time when these sources/activities were used/conducted in order to cross-reference them with concentration levels. The second questionnaire focused on occupancy/activities of room where sampling equipment was placed. The last questionnaire focused on the schedule of children's activities and their physical activity during sampling. All necessary permissions were obtained from administrative boards of each preschool and directly from parents.

\section{Dose Rate Analysis}

Particle dose rates for children were calculated using Eq. (1) (Castro et al., 2011; Slezakova et al., 2014):

Dose rate $(\mathrm{D})=\left(\mathrm{BR}_{\mathrm{WA}} / \mathrm{BW}\right) \times \mathrm{C}_{\mathrm{WA}} \times \mathrm{OF} \times \mathrm{N}$

where $D$ is the age-specific dose rate (particle number $/ \mathrm{kg} /$ day); $B R_{W a}$ is the age-specific weighted average breathing rate $(\mathrm{L} / \mathrm{min})$; $\mathrm{BW}$ is age-specific body weight $(\mathrm{kg}) ; \mathrm{C}_{\mathrm{WA}}$ is the age-specific weighted average concentration of particles (number of particles/L); OF is the occupancy factor (i.e., percentage of residents likely to be in the microenvironment at a given interval; it was considered 1, as children kept to their schedules and associated locations tightly); and $\mathrm{N}$ is the total time per day spent by age-specific children in the respective indoor environment $(\mathrm{min} / \mathrm{d})$. Particle dose rates were estimated for 3- to 4-yr-old and 5 -yr-old children. The daily activity patterns of children were analyzed throughout each day. Locations in which the different activities occurred during the day were identified. Total daily residence time of children spent in each microenvironment (home, preschool) and the types of performed activities were registered.
Each activity was characterized in terms of intensity level in order to assess the corresponding BR. An example of children's timetable and activity patterns is shown in Table 2. As the information concerning the Portuguese population is not available, age-specific factors of body weight (BW) and breathing rate (BR) were retrieved from U.S. Environmental Protection Agency (EPA) data (U.S. EPA, 2011) considering the mixed population (both male and females). BW of $18.6 \mathrm{~kg}$ for children 3-5 years old was used. The values of BR were selected as the followings: $4.3 \mathrm{~L} / \mathrm{min}$ for rest or sleep; $4.5 \mathrm{~L} / \mathrm{min}$ for sedentary or passive activities; $11 \mathrm{~L} / \mathrm{min}$ for light intense activity; and $37 \mathrm{~L} / \mathrm{min}$ for highly intense activities such as running. BR $R_{W A}$ was estimated as a weighted average, that is, considering the intensity of each performed activity and the amount of time. The dose rates were then estimated using the average indoor concentrations of each microenvironment and considering the real amount of time that children spent in each place.

\section{Statistical Analysis}

For the data treatment, Student's t-test was applied to determine the statistical significance ( $p<.05$, two-tailed) of the differences between the determined means. All statistical analyses were performed using IBM SPSS Statistics software.

\section{RESULTS}

\section{Particle Number Concentrations}

Total means of particle number concentrations and statistical parameters (minimum and maximum values, 25th and 75th percentiles) at the two preschools and three homes are shown in Figure 1. These parameters of (ultra)fine particles were determined using all measured data of all examined indoor environments. Concerning the two preschools, mean of indoor PNC was significantly 1.4-fold higher at S1 $\left(1.84 \times 10^{4}\right.$ particles $\left./ \mathrm{cm}^{3}\right)$ than at S2 (mean of $1.32 \times 10^{4}$ particles $\left./ \mathrm{cm}^{3}\right)$. 
TABLE 2. Timetable and Child Activity Patterns During a Weekday: An Example for Children 3-4 yr Old at School and a Home

\begin{tabular}{|c|c|c|c|c|}
\hline Time & & Environment & Observed activities & $\begin{array}{l}\text { Activity } \\
\text { intensity }\end{array}$ \\
\hline \multicolumn{5}{|l|}{ School } \\
\hline 8:30-9:00 & Arrival at school & Indoor & Playing (calm, seated, TV) & Sedentary \\
\hline $9: 03-10: 29$ & Classes/education & Indoor & Seated only (talking) & Sedentary \\
\hline $10: 30-11: 15$ & Recess & Playground & Running, jumping, swings & High intensity \\
\hline $11: 17-11: 40$ & Classes/education & Indoor & Sedentary and other (painting, walking) & Sedentary \\
\hline $11: 45-13: 00$ & Lunch & Indoor & Seated (eating, drinking, talking) & Light \\
\hline $13: 05-15: 00$ & Rest & Indoor & Sleeping & Sleep \\
\hline 15:04-16:00 & Classes/education & Indoor & Seated, and other & Sedentary \\
\hline $16: 00-17: 30$ & Leaving school & Indoor & Organized activities (singing dancing), running & High intensity \\
\hline \multicolumn{5}{|l|}{ Home } \\
\hline 18:00-19:20 & Living room & & Home works, school preparation, studying & Sedentary \\
\hline 19:25-20:00 & Living room & & Seated (eating, drinking, talking) & Sedentary \\
\hline $20: 05-: 22: 00$ & Living room & & Playing games, painting, walking & Light \\
\hline $22: 00-6: 50$ & Bedroom & & Sleeping & Sleep \\
\hline $7: 00-8: 00$ & Various & & Morning routine, breakfast & Light \\
\hline
\end{tabular}

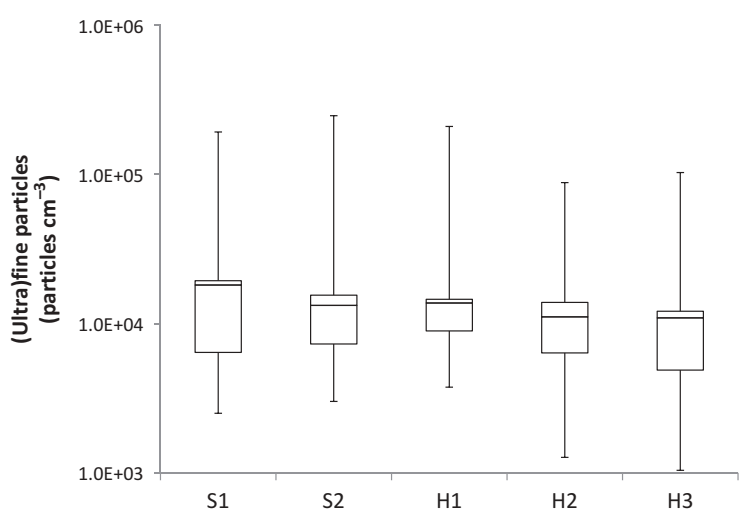

FIGURE 1. Levels of (ultra)fine particles at two schools ( $\mathrm{S} 1$, S2) and three homes $(\mathrm{H} 1-\mathrm{H} 3)$ : minimum and maximum values, average, and 25th and 75th percentiles. Particle number concentrations were determined considering the measured levels in all indoor microenvironments existent in each school and home.

At all three homes, obtained means of indoor (ultra)fine particles (Table 1) were rather similar; the results showed that the total indoor means of PNC at the three homes were not statistically different. Overall, the highest mean and ranges of PNC were observed at $\mathrm{H} 1$ with mean concentration 1.1-fold higher than at $\mathrm{H} 2$ and $\mathrm{H} 3$.

\section{Dose Rates}

The activities that children conducted during their school time were similar at both preschools. However, dose rates of indoor particles were estimated for 2 age categories, namely, children 3-4 yr old and 5 yr old, because their daily schedules differed slightly. Children spent the majority of their preschool time in classrooms (approximately $70-75 \%$ for 3-4 yr old, and $57-70 \%$ for $5 \mathrm{yr}$ old). The younger children rested (i.e., slept, which was an activity associated with the lowest breathing rates) after lunch for 2-2.5 h, whereas older children performed indoors more frequently physical activities such as running, playing, exercising, and use of climbers, swings, and slide. In addition, the 5-yr-old children spent less time (0.75-1.75 h) indoors. Overall, the daily activity patterns of children at the three homes were remarkably similar. On average, children spent $13 \mathrm{~h}$ at home, out of which $3 \mathrm{~h}$ occurred in a living room (sedentary or light activities; studying, games playing, drawing, or eating). Morning and evening routines (breakfast, bath, etc.) took approximately $1 \mathrm{~h}$, whereas children slept for about $9 \mathrm{~h}$.

Dose rates associated with inhalation exposure to (ultra)fine particles (20-1000 nm) number concentrations at the two preschools and three homes were estimated for two different age categories of children. The results are shown in Table 3. Concerning preschools, the data demonstrate that (i) for both age categories 
TABLE 3. Age-Specific Dose Rates (particles/kg/d) to UFP for Children (3-4 yr and 5 yr Old) at Two Preschools (S1 and S2) and Three Homes $(\mathrm{H} 1-\mathrm{H} 3)$

\begin{tabular}{|c|c|c|c|c|c|c|c|}
\hline & S1 & & S2 & & $\mathrm{H} 1$ & $\mathrm{H} 2$ & $\mathrm{H} 3$ \\
\hline $\begin{array}{l}\text { Dose rate } \\
\quad \text { (particles } / \mathrm{kg} / \mathrm{d})\end{array}$ & $\begin{array}{l}3-4 \text { yr old } \\
1.99 \times 10^{9}\end{array}$ & $\begin{array}{l}5 \mathrm{yr} \text { old } \\
2.02 \times 10^{9}\end{array}$ & $\begin{array}{l}3-4 \mathrm{yr} \text { old } \\
1.49 \times 10^{9}\end{array}$ & $\begin{array}{l}5 \mathrm{yr} \text { old } \\
1.92 \times 10^{9}\end{array}$ & $\begin{array}{l}3-5 \text { yr old } \\
3.06 \times 10^{9}\end{array}$ & $\begin{array}{l}3-5 \mathrm{yr} \\
2.74 \times 10^{9}\end{array}$ & $\begin{array}{l}3-5 \text { yr old } \\
2.69 \times 10^{9}\end{array}$ \\
\hline
\end{tabular}

the highest dose rates of PNC were found at S1; and (ii) for both schools the highest values of PNC total dose rates were observed for 5-yr-old children. Further, the results in Table 3 illustrate that for children 3-4 yr and $5 \mathrm{yr}$ old, dose rates at homes were 1.3- to 2.1-fold higher than at schools.

\section{DISCUSSION}

As children represent one of the most susceptible subpopulations in society, more information concerning air pollutants to which they are exposed in schools and home environments is needed. Overall, levels of (ultra)fine particles at the two Portuguese preschools were similar in range to those reported for indoor air of schools in Greece $\left(2.4 \times 10^{4}\right.$ particles $/ \mathrm{cm}^{3}$; Diapouli et al., 2008), Italy (1.95-2.04 × 104 particles $/ \mathrm{cm}^{3}$; Buonanno et al., 2012, 2013a), Spain $\left(1.56 \times 10^{4}\right.$ particles $/ \mathrm{cm}^{3}$; Reche et al., 2014; Rivas et al., 2014), South Korea (1.82 $\times 10^{4}$ particles $/ \mathrm{cm}^{3}$; Kim et al., 2011), and Australia (1.21-1.69 × 10 particles $/ \mathrm{cm}^{3}$; Rumchev et al., 2007). In addition, a large ongoing epidemiological study of UFP in schools was conducted in Melbourne (Australia) (Mazaheri et al., 2014). Other studies from Europe, namely, in Denmark, Germany, and Sweden (Clausen et al., 2012; Fromme et al., 2007; Norbäck et al., 2011), noted lower levels of UFP $\left(0.7 \times 10^{3}-6.5 \times 10^{3}\right.$ particles $\left./ \mathrm{cm}^{3}\right)$ than in the present study. Different levels of urbanization and development of the area surrounding schools, meteorological conditions, or seasonal influences might account for some of these differences (Morawska et al., 2009). It is also necessary to indicate that the majority of the existing studies on UFP in educational settings focused on assessments in classrooms (Clausen et al., 2012; Fromme et al., 2007;
Guo et al., 2010; Mullen et al., 2011; Norbäck et al., 2011; Weichenthal et al., 2008). Zhang and Zhu (2012) also reported the information on UFP in other school microenvironments: gymnasium, canteen, and libraries. In this investigation, classrooms were the microenvironment associated with lower particle number concentrations at both preschools (mean of $9.31 \times 10^{3}$ and $1.13 \times 10^{4}$ particles $/ \mathrm{cm}^{3}$ at $\mathrm{S} 1$ and S2, respectively), which is reassuring, considering that these are the sites where children spend the majority of their school time. The major identified sources of (ultra)fine particles, based on daily registered information, were classroom cleaning children's activities during classes, such as sculpting, and combustion sources; levels of (ultra)fine particles in ambient air ranged from $2.4 \times 10^{3}$ to $4.3 \times 10^{4}$ (Slezakova et al., 2014). In contrast, at both preschools the highest PNC were observed in canteens (mean of $5.17 \times 10^{4}$ and $3.28 \times 10^{4}$ particles $/ \mathrm{cm}^{3}$ at S1 and S2, respectively). Although children spend short periods of time (18 and $19 \%$ of their school time at S1 and S2, respectively) in canteens, exposure in this type of indoor microenvironment might be relevant for overall child school exposure. In addition, exposure to high levels of UFP numbers, even if during a limited period of time, may pose some risks to child health (Burtscher and Schüepp, 2012). In agreement with these findings, Mullen et al. (2011) previously reported that cooking events were the most significant indoor sources (during normal occupancy) at six schools in California. The importance of cooking and eating activities was also demonstrated in more recent studies evaluating particle deposition in the alveolar and tracheobronchial region (Buonanno et al., 2011, 2012, 2013b; Mazaheri et al., 2013). 
At the three homes the mean concentrations of particles number ranged between $1.09 \times 10^{4}$ and $1.24 \times 10^{4}$ particles $/ \mathrm{cm}^{3}$. These levels of PNC were similar to mean concentrations reported in literature for homes in Germany $\left(0.9 \times 10^{4}\right.$ particles $/ \mathrm{cm}^{3}$; Fittschen et al., 2013), Greece (1.3-1.4 × 104 particles $/ \mathrm{cm}^{3}$; Diapouli et al., 2011), Canada (0.8-1.03 × $10^{4}$ particles $/ \mathrm{cm}^{3}$; Kearney et al., 2011; Wheeler et al., 2011), and Australia $\left(1.24 \times 10^{4}\right.$ particles $/ \mathrm{cm}^{3}$; Morawska et al., 2003). However, recently Bekö et al. (2013) conducted a large study that assessed UFP in 56 residences in Denmark and found levels approximately threefold higher than in Portuguese homes (mean of $2.91 \times 10^{4}$ particles/ $\mathrm{cm}^{3}$; Bekö et al., 2013). Different study design (sampling period, duration, number of homes) and/or different particle size ranges of measured ultrafine fraction might also contribute to these differences (Morawska et al., 2013).

Overall, the highest mean of $\mathrm{PNC}$ and the maximal levels $\left(2.1 \times 10^{5}\right.$ particles $\left./ \mathrm{cm}^{3}\right)$ were observed at $\mathrm{H} 1$. Based on the analysis of information available from the questionnaires, indoor sources of UFP at $\mathrm{H} 1$ included cooking (boiling and frying), use of toaster and oven, use of cleaning products, vacuuming, and ironing. Certainly the frequency and durations of these indoor activities might have influenced the respective levels. However, it is also necessary to indicate that, contrary to the other two homes, at $\mathrm{H} 1$ the room where sampling was conducted was directly connected with a kitchen. In addition, occupants of this home maintained doors between kitchen and living room almost constantly open. Thus, PNC from cooking emissions easily penetrated the sampling area (Bordado et al., 2012; Buonanno et al., 2013b), and accounted for high concentrations at this home. The variation of time and location (room type) might account for the obtained differences of (ultra)fine particles (Bekö, et al., 2013).

Overall, the levels of PNC at the three homes were $10-70 \%$ lower than at preschools. However, activities (and the levels of their physical intensity) that are typically performed in an educational institution vary greatly from those of homes. Therefore, the dose rates resulting from a stay in these two environments might differ considerably.

The highest doses of PNC at preschools were found for children of S1 (Table 3). Although levels of PNC in classrooms were highest at S2, doses of UFP resulting from school exposure were higher (up to $50 \%$ ) for children at S1, probably due to the higher levels of PNC in the canteen of respective preschool. These findings thus demonstrate that all potential microenvironments need to be considered when assessing children's exposure to PNC in preschools and schools.

The estimated dose rates of indoor PNC at both schools were compared between both age groups of children. The results in Table 3 showed that at S2 dose rates were higher for 5yr-old children. As mentioned previously, older children performed more frequently physical activities that were associated with the highest $\mathrm{BR}$ and consequently led to higher inhalation doses of particles. In contrast, children 3-4 yr old spent more time in classrooms, where levels of PNC were lowest. Further, after lunch children 3-4 yr old slept in classrooms, which was an activity associated with the lowest BR. At S1, the estimated dose rates were not statistically different between children 3-4 yr old and $5 \mathrm{yr}$ old, which was probably due to different activity patterns; older children spent $1.75 \mathrm{~h}$ less indoors, and contributions resulting from the outdoor exposure were not considered in this study. Therefore, in future investigations when assessing children, a period spent during school daytime outdoors needs to be considered, as it might be relevant to child overall school exposure.

When evaluating the three homes (Table 3), the highest dose rates of particles were observed for children at $\mathrm{H} 1$ due to the highest levels of UFP at this home. When in use, particles samplers make minor noise. Therefore, in order to maintain soundless rest of children it was not possible to conduct measurements directly in children's bedrooms. The obtained dose rates of PNC at $\mathrm{H} 1-$ $\mathrm{H} 3$ thus represent an approximation of child 
home exposure and need to be interpreted carefully.

Finally, dose rates of particles in the (ultra)fine range at homes were higher than those of preschools. Although number concentrations of (ultra)fine particles at the three homes were lower than total levels at both preschools (Figure 1), children spent approximately $13 \mathrm{~h}$ at homes (opposed to $9 \mathrm{~h}$ at preschools). The longer exposure time might account for the obtained values. Data thus indicate that daily activity patterns significantly influenced overall doses to PNC in children $3-5$ yr old.

The dose rates of (ultra)fine particles estimated in this study were due to study indoor exposure at preschools and homes. However, on a daily basis children spend some of their time in other microenvironments such as transportation modes and extracurricular activities, where they are exposed to UFP from additional sources. Therefore, characterization of the respective exposures to UFP for children in these microenvironments is of utmost importance. Future studies focusing on health effects of airborne pollutants always need to account for children's exposures in different microenvironments including homes, schools, and transportation modes in order to obtain a correct representation of children's overall exposure.

\section{FUNDING}

This work was supported by Fundação para Ciência e Tecnologia with grant number SFRH/BPD/65722/2009. It also received financial support from the European Union (FEDER funds through COMPETE) and National Funds (Fundação para a Ciência e Tecnologia) through projects UID/EQU/00511/2013LEPABE and Pest-C/EQB/LA0006/2013.

\section{REFERENCES}

Annesi-Maesano, I., Baiz, N., Banerjee, S., Rudnai, P., and Rive, S., on behalf of Sinphonie Group. 2013. Indoor air quality and sources in schools and related health effects. J. Toxicol Environ. Health $B$ 16: 491-550.

Azarmi, F., Kumar, P., and Mulheron, M. 2014. The exposure to coarse, fine and ultrafine particle emissions from concrete mixing, drilling and cutting activities. J. Hazard. Mater. 279: 268-279.

Bakand, S., Hayes, A., and Dechsakulthorn, F. 2012. Nanoparticles: A review of particle toxicology following inhalation exposure. Inhal. Toxicol. 24: 125-135.

Bhangar, S., Mullen, N. A., Hering, S. V., Kreisberg, N. M., and Nazaroff, W. W. 2011. Ultrafine particle concentrations and exposures in seven residences in northern California. Indoor Air 21: 132-144.

Bekö, G., Weschler, C. J., Wierzbicka, A., Karottki, D. G., Toftum, J., Loft, S., and Clausen, G. 2013. Ultrafine particles: Exposure and source apportionment in 56 Danish homes. Environ. Sci. Technol. 47: 10240-10248.

Bordado, J. C., Gomes J. F., and Albuquerque P. C. 2012. Exposure to airborne ultrafine particles from cooking in Portuguese homes. J. Air Waste Manage. Assoc. 62: 1116-1126.

Brunekreef, B., Beelen, R., Hoek, G., Schouten, L., Bausch-Goldbohm, S., Fischer, P., Armstrong, B., Hughes, E., Jerrett, M., and van den Brandt, P. 2009. Effects of long-term exposure to traffic-related air pollution on respiratory and cardiovascular mortality in the Netherlands: The NLCS-AIR study. Res. Rep. Health Effects Inst. 139: 5-71.

Buonanno, G., Fuoco, F. C., Morawska, L., and Stabile, L. 2013a. Airborne particle concentrations at schools measured at different spatial scales. Atmos. Environ. 67: 38-45.

Buonanno, G. Giovinco, G., Morawska, L., and Stabile, L. 2011. Tracheobronchial and alveolar dose of submicrometer particles for different population age groups in Italy. Atmos. Environ. 45: 6216-6224.

Buonanno, G., Marini, S., Morawska, L., and Fuoco, F. C. 2012. Individual dose and exposure of Italian children to ultrafine particles. Sci. Total Environ. 438: 271-277.

Buonanno, G., Morawska, L, Stabile, L., Wang, L., and Giovinco, G. 2012. A comparison 
of submicrometer particle dose between Australian and Italian people. Environ. Pollut. 169: 183-189.

Buonanno, G., Stabile, L., Morawska, L., and Russi, A. 2013b. Children exposure assessment to ultrafine particles and black carbon: The role of transport and cooking activities. Atmos. Environ. 79: 53-58.

Burtscher, H., and Schüepp, K. 2012. The occurrence of ultrafine particles in the specific environment of children. Paediatr. Respir. Rev. 13: 89-94.

Carosino, C. M., Bein, K. J., Plummer, L. E., Castandea, A. R., Zhao, Y., Wexler, A. S., and Pinkerton K. E. 2015. Allergic airway inflammation is differentially exacerbated by daytime and nighttime ultrafine and submicron fine ambient particles: Heme oxygenase- 1 as an indicator of PM-mediated allergic inflammation. J. Toxicol. Environ. Health A 78: 254-266.

Castro, D., Slezakova, K., Delerue-Matos, C., Alvim-Ferraz, M. C., Morais, S., and Pereira, M. C. 2011. Polycyclic aromatic hydrocarbons in gas and particulate phases of indoor environments influenced by tobacco smoke: Levels, phase distributions, and health risks. Atmos. Environ. 45: 1799-1808.

Chang, C.-C., Chen, P.-S., and Yang, C.-Y. 2015. Short-term effects of fine particulate air pollution on hospital admissions for cardiovascular diseases: A case-crossover study in a tropical city. J. Toxicol. Environ. Health A 78: 267-277.

Clausen, G., Høst, A., Toftum, J., Bekö, G., Weschler, C., Callesen, M., Buhl, S., Ladegaard, M. B., Langer, S., Andersen, B., Sundell, J., Bornehag, C. G., and Sigsgaard, T. 2012. Children's health and its association with indoor environments in Danish homes and daycare centres-Methods. Indoor Air 22: 467-475.

Diapouli, E., Chaloulakou, A., and Spyrellis, N. 2007. Levels of ultrafine particles in different microenvironment-Implications to children exposure. Sci. Total Environ. 388: 128-136.

Diapouli, E., Eleftheriadis, K., Karanasiou, A. A., Vratolis, S., Hermansen, O., Colbeck, I., and Lazaridis, M. 2011. Indoor and outdoor particle number and mass concentrations in Athens. Sources, sinks and variability of aerosol parameters. Aerosol Air Qual. Res. 11: 632-642.

Diapouli, E., Chaloulakou, A., Mihalopoulos, N., and Spyrellis, N. 2008. Indoor and outdoor PM mass and number concentrations at schools in the Athens area. Environ. Monit. Assess. 136: 13-20.

Fittschen, U. E. A., Santen, M., Rehmers, A., Durukan, I., and Wesselmann, M. 2013. Indoor aerosol determination with respect to a soiling phenomenon in private residences. Environ. Sci. Technol. 47: 608-615.

Foos, B., Marty, M., Schwartz, J., Bennett, W., Moya, J., Jarabek, A. M., and Salmon, A. G. 2008. Focusing on children's inhalation dosimetry and health effects for risk assessment: An introduction. J. Toxicol. Environ. Health A 71: 149-165.

Fromme, H., Twardella, D., Dietrich, S., Heitmann, D., Schierl, R., Liebl, B., and Rüden, H. 2007. Particulate matter in the indoor air of classrooms-Exploratory results from Munich and surrounding area. Atmos. Environ. 41: 854-866.

Guo, H., Morawska, L., He, C., Zhang, Y. L., Ayoko, G., and Cao, M. 2010. Characterization of particle number concentrations and PM2.5 in a school: Influence of outdoor air pollution on indoor air. Environ. Sci. Pollut. Res. 17: 1268-1278.

Heal, M. R., Kumar, P., and Harrison, R. M. 2012. Particles, air quality, policy and health. Chem. Soc. Rev. 41: 6606-6630.

Ibald-Mulli, A., Wichmann, H. E., Kreyling, W., and Peters, A. 2002. Epidemiological evidence on health effects of ultrafine particles. J. Aerosol. Med. 15: 189-201.

Kearney, J., Wallace, L., MacNeill, M., Xu, X., Vanryswyk, K., You, H., Kulka, R., and Wheeler, A. 2011. Residential indoor and outdoor ultrafine particles in Windsor, Ontario. Atmos. Environ. 45: 7583-7593.

Kelly, F. J., and Fussell, J. C. 2012. Size, source and chemical composition as determinants of toxicity attributable to ambient particulate matter. Atmos. Environ. 60: 504-526. 
Kim, J.-L., Elfman, L., Wieslander, G., Ferm, M., Torén, K., and Norbäck, D. 2011. Respiratory health among Korean pupils in relation to home, school and outdoor environment. J. Korean Med. Sci. 26: 166-173.

Krewski, D., Burnett, R. T., Goldberg, M. S., Hoover, B. K., Siemiatycki, J., Jerrett, M., Abrahamowicz, M., and White, W. H. 2003. Overview of the reanalysis of the Harvard Six Cities Study and American Cancer Society study of particulate air pollution and mortality. J. Toxicol. Environ. Health A 66: 1507-1551.

Krewski, D., and Rainham, D. 2007. Ambient air pollution and population health: Overview. J. Toxicol. Environ. Health $A$ 70: 275-283.

Kumar, P., Robins, A., Vardoulakis, S., and Britter, R. 2010. A review of the characteristics of nanoparticles in the urban atmosphere and the prospects for developing regulatory controls. Atmos. Environ. 44: 5035-5052.

Laiman, R., He, C., Mazaheri, M., Clifford, S., Salimi, F., Crilley, L. R., Megat Mokhtar, M. A., and Morawska, L. 2014. Characteristics of ultrafine particle sources and deposition rates in primary school classrooms. Atmos. Environ. 94:28-35.

Long, C. M., Suh, H. H., and Koutrakis, P. 2000. Characterization of indoor particle sources using continuous mass and size monitors. J. Air Waste Manage. Assoc. 50: 1236-1250.

Mazaheri, M., Clifford, S., Jayaratne, R., Megat Mokhtar, M. A., Fuoco, F., Buonanno, G., and Morawska, L. 2014. School children's personal exposure to ultrafine particles in the urban environment. Environ. Sci. Technol. 48: 113-120.

Morawska, L., Afshari, A., Bae, G. N., Buonanno, G., Chao, C. Y. H., Hänninen, O., Hofmann, W., Isaxon, C., Jayaratne, E. R., Pasanen, P., Salthammer, T., Waring M., and Wierzbicka A. 2013. Indoor aerosols: From personal exposure to risk assessment. Indoor Air 23: 462-487.

Morawska, L., He, C., Hitchins, J., Mengersen, K., and Gilbert, D. 2003. Characteristics of particle number and mass concentrations in residential houses in Brisbane, Australia. Atmos. Environ. 37: 4195-4203.

Morawska, L., He, C., Johnson, G., Guo, H., Uhde, E., and Ayoko, G. 2009. Ultrafine particles in indoor air of a school: Possible role of secondary organic aerosols. Environ. Sci. Technol. 43: 9103-9109.

Morawska, L., Ristovski, Z., Jayaratne, E. R., Keogh, D. U., and Ling, X. 2008. Ambient nano and ultrafine particles from motor vehicle emissions: Characteristics, ambient processing and implications on human exposure. Atmos. Environ. 42: 8113-8138.

Moreno, T., Rivas, I., Bouso, L., Viana, M., Jones, T., Àlvarez-Pedrerol, M., Alastuey, A., Sunyer, J., and Querol, X. 2014. Variations in school playground and classroom atmospheric particulate chemistry. Atmos. Environ. 91: 162-171.

Mullen, N. A., Bhangar, S., Hering, S. V., Kreisberg, N. M., and Nazaroff, W. W. 2011. Ultrafine particle concentrations and exposures in six elementary school classrooms in northern California. Indoor Air 21: 77-87.

Norbäck, D., Wieslander, G., Zhang, X., and Zhao, Z. 2011 Respiratory symptoms, perceived air quality and physiological signs in elementary school pupils in relation to displacement and mixing ventilation system: an intervention study. Indoor Air 21: 427-437.

Pereira Gomes, J. F., Moura Bordado, J. C., and Silva Albuquerque, P. C. 2012. On the assessment of exposure to airborne ultrafine particles in urban environments. J. Toxicol. Environ. Health A 75: 1316-1329.

Reche, C., Viana, M., Rivas, I., Bouso, L., Àlvarez-Pedrerol, M., Alastuey, A., Sunyer, J., and Querol, X. 2014. Outdoor and indoor UFP in primary schools across Barcelona. Sci. Total Environ. 493: 943-953.

Rivas, I., Viana, M., Moreno, T., Bouso, L., Pandolfi, M., Alvarez-Pedrerol, M., Forns, J., Alastuey, A., Sunyer, J., and Querol, X. 2015. Outdoor infiltration and indoor contribution of UFP and BC, OC, secondary inorganic ions and metals in PM2.5 in schools. Atmos. Environ. 106: 129-138. 
Rivas, I., Viana, M., Moreno, T., Pandolfi, M., Amato, F., Reche, C., Bouso, L., Àlvarez-Pedrerol, M., Alastuey, A., Sunyer, J., and Querol, X. 2014. Child exposure to indoor and outdoor air pollutants in schools in Barcelona, Spain. Environ. Int. 69: 200-212.

Rückerl, R., Schneider, A., Breitner, S., Cyrys, J., and Peters, A. 2011. Health effects of particulate air pollution: A review of epidemiological evidence. Inhal. Toxicol. 23: 555-592.

Rumchev, K., Ourangui, R., Bertolatti, D., and Spickett, J. 2007. Indoor air quality in old and new schools. WIT Trans. Biomed. Health 11: $25-32$.

Samet, J., and Krewski, D. 2007. Health effects associated with exposure to ambient air pollution. J. Toxicol. Environ. Health A 70: 227-242.

Schüepp, K., and Sly, P. D. 2012. The developing respiratory tract and its specific needs in regard to ultrafine particulate matter exposure. Paediatr. Respir. Rev. 13: 95-99.

Schwab, M., McDermott, A., and Spengler, J. D. 1992. Using longitudinal data to understand children's activity patterns in an exposure context: Data from the Kanawha County Health Study. Environ. Int. 18: 173-189.

Slezakova, K., Castro, D., Begonha, A., Delerue-Matos, C., Alvim-Ferraz, M. C., Morais, S., and Pereira, M. C. 2011. Air pollution from traffic emissions in Oporto, Portugal: Health and environmental implications. Microchem. J. 99: 51-59.

Slezakova, K., Fonseca, J., Morais, S., and Pereira, M. C. 2014. Ultrafine particles in ambient air of an urban area: Dose implications for elderly. J. Toxicol. Environ. Health A 77: 827-836.

Slezakova, K., Pires, J. C. M., Castro, D., AlvimFerraz, M. C. M., Delerue-Matos, C., Morais, S., and Pereira, M. C. 2013. PAH air pollution at a Portuguese urban area: Carcinogenic risks and sources identification. Environ. Sci. Pollut. Res. Int. 20: 3932-3945.
Solomon, P. A. 2012. An overview of ultrafine particles in ambient air. EM May: 18-23.

Tsai, S.-S., and Yang, C.-Y. 2014. Fine particulate air pollution and hospital admissions for pneumonia in a subtropical city: Taipei, Taiwan. J. Toxicol. Environ. Health A 77: 192-201.

U.S. Environmental Protection Agency. 2011. Exposure factors handbook: 2011 Edition. EPA/600/R-09/052F. Washington, DC: U.S. EPA Office for Research and Development.

Viana, M., Rivas, I., Querol, X., Alastuey, A., Álvarez-Pedrerol, M., Bouso, L., Sioutas, C., and Sunyer, J. 2015. Partitioning of trace elements and metals between quasi-ultrafine, accumulation and coarse aerosols in indoor and outdoor air in schools. Atmos. Environ. 106: 392-401.

Viana, M., Rivas, I., Querol, X., Alastuey, A., Sunyer, J., Álvarez-Pedrerol, M., Bouso, L., and Sioutas, C. 2014. Indoor/outdoor relationships and mass closure of quasi-ultrafine, accumulation and coarse mode particles in Barcelona schools. Atmos. Chem. Phys. 14: 4459-4472.

Wang, Y., Hopke, P. K., Chalupa, D. C., and Utell, M. J. 2011. Long-term study of urban ultrafine particles and other pollutants. Atmos. Environ. 45: 7672-7680.

Weichenthal, S., Dufresne, A., Infante-Rivard, C., and Joseph, L. 2008. Characterizing and predicting ultrafine particle counts in Canadian classrooms during the winter months: Model development and evaluation. Environ. Res. 106: 349-360.

Wheeler, A. J., Wallace, L. A., Kearney, J., Van Ryswyk, K., You, H., Kulka, R., Brook, J. R., and Xu, X. 2011. Personal, indoor, and outdoor concentrations of fine and ultrafine particles using continuous monitors in multiple residences. Aerosol Sci. Technol. 45: 1078-1089.

Zhang, Q., and Zhu, Y. 2012. Characterizing ultrafine particles and other air pollutants at five schools in South Texas. Indoor Air 22: 33-42. 